\title{
In vitro ruminal fermentation kinetics of diets with crambe cake protein replacing soybean meal protein by gas production technique
}

\section{Cinética de fermentação ruminal in vitro de dietas com proteína de torta de crambe em substituição à proteína do farelo de soja pela técnica de produção de gás}

\author{
Angela Rocio Poveda-Parra1*; Odimári Pricila Prado-Calixto'; Elzânia Sales \\ Pereira ${ }^{2}$; Fernando Luiz Massaro Junior ${ }^{3}$; Larissa Nóbrega de Carvalho4; Geisi \\ Loures Guerra3; Camila Cano Serafim ${ }^{5}$; Elias Rodrigues Cavalheiro Junior ; \\ Leandro das Dores Ferreira da Silva ${ }^{1}$; Ivone Yurika Mizubuti ${ }^{1}$
}

\section{Highlights}

In vitro techniques are used to characterize the ruminal metabolism of animals.

Crambe is a subtropical plant, with high protein (200-300 $\left.\mathrm{g} \mathrm{kg}^{-1}\right)$ and energy contents.

The crambe cake showed a good ruminal fermentation kinetic profile.

\section{Abstract}

The objective of this study was to evaluate ingredients and diets containing increasing levels of crambe cake protein replacing soybean meal protein, with in vitro ruminal fermentation parameters using a gas production technique. Diets were formulated for feedlot lambs and contained different levels of crambe cake protein $\left(0,250,500,750\right.$, and $\left.1000 \mathrm{~g} \mathrm{~kg}^{-1}\right)$ replacing soybean meal protein. Corn silage was used as roughage. Carbohydrate digestion rates were estimated using the in vitro gas production technique and the cumulative gas production kinetics were analyzed using the bicompartmental logistic model. The parameters values of ruminal degradation kinetics were generated using the $\mathrm{R}$ statistical program with the Gauss-Newton algorithm and then subjected to analysis of variance and regression (when necessary) according to a completely randomized experimental design with five treatments and five replications. Upon carbohydrate fractionation of ingredients and experimental diets, it was observed that corn grain and corn

1 Profs. Drs., Department of Animal Science, Universidade Estadual de Londrina, UEL, Londrina, PR, Brazil. E-mail: angelpov@gmail.com; odimari@uel.br; leandro@uel.br; mizubuti54@hotmail.com

2 Profa Dra, Department of Animal Science, Universidade Federal do Ceará, UFC, Fortaleza, CE, Brazil. E-mail: elzania@ hotmail.com

3 Drs. of Animal Science, UEL, Londrina, PR, Brazil. E-mail: massaro@uel.br; geisi_guerra@hotmail.com;

4 Master of Animal Science, UEL, Londrina, PR, Brazil. E-mail: larissanobrega@zootecnista.com.br

5 Students of the PhD Course of Postgraduate Program in Animal Science, UEL, Londrina, PR, Brazil. E-mail: camilacanoserafim@hotmail.com; elias.cavalheiro@uel.br

* Author for correspondence

Received: Nov. 28, 2020 - Approved: July 03, 2021 
silage presented the highest levels of total carbohydrates (TC), with values of 128.3 and $464.8 \mathrm{~g} \mathrm{~kg}^{-1} \mathrm{dry}$ matter (DM) in fraction B2, respectively. Lower TC content was found for soybean meal and crambe cake (CC). There was a predominance of fractions $A+B 1$ in the ingredients and experimental diets. The B2 fraction decreased in the diets with the inclusion of the $\mathrm{CC}$ protein, and $\mathrm{CC}$ presented the highest $\mathrm{C}$ fraction. Protein fractionation ( $\mathrm{g} \mathrm{kg}^{-1} \mathrm{DM}$ and $\mathrm{g} \mathrm{kg}^{-1}$ crude protein - CP), the ingredients and diets showed a higher proportion of fractions $A$ and B1 + B2. In in vitro degradation, the diet without $\mathrm{CC}\left(0 \mathrm{~g} \mathrm{~kg}^{-1} \mathrm{DM}\right)$ showed the highest final cumulative gas production ( $365.04 \mathrm{~mL} \mathrm{~g}^{-1}$ of incubated DM), while the CC presented the lowest volume (166.68 $\mathrm{mL} \mathrm{g}^{-1}$ of incubated DM). The gas volume of non-fibrous carbohydrate fermentation and fibrous carbohydrate degradation rate exhibited a quadratic effect according increasing levels of CC (Pmax $=265.8$ $\mathrm{g} \mathrm{kg}^{-1} \mathrm{DM}$ and Pmin $=376.3 \mathrm{~g} \mathrm{~kg}^{-1} \mathrm{DM}$, respectively). The lag time and final gas volume showed a decreasing linear effect with increasing levels of $\mathrm{CC}$ protein. The degradation rate of non-fibrous carbohydrates and the final volume of fibrous carbohydrates did not differ. Replacing soybean meal protein with CC protein at the level of $250 \mathrm{~g} \mathrm{~kg}^{-1}$ of dry matter in diets formulated for feedlot lambs leads to good profiles of ruminal fermentation kinetics with respect to the degradation of fibrous and non-fibrous carbohydrates.

Key words: Biodiesel. Byproduct. Carbohydrate fraction. In vitro degradation. Protein fraction.

\section{Resumo}

O objetivo deste estudo foi avaliar ingredientes e dietas contendo diferentes níveis de proteína da torta de crambe como substituto da proteína do farelo de soja utilizando parâmetros de fermentação ruminal in vitro pela técnica de produção de gás. Foram formuladas dietas para cordeiros em confinamento e continham níveis crescentes de proteína da torta de crambe $\left(0,250,500,750\right.$, e $\left.1000 \mathrm{~g} \mathrm{~kg}^{-1}\right)$ em substituição à proteína do farelo de soja. A silagem de milho foi utilizada como volumoso. As taxas de digestão de carboidratos foram estimadas usando a técnica in vitro de produção de gás, e a cinética cumulativa de produção de gás foi analisada usando o modelo logístico bicompartimental. Os valores dos parâmetros da cinética de degradação ruminal foram gerados usando o programa estatístico R com o algoritmo de Gauss-Newton e posteriormente submetidos à análise de variância e regressão (quando necessário) em delineamento experimental inteiramente casualizado com cinco tratamentos e cinco repetições. Sobre o fracionamento dos carboidratos dos ingredientes e das dietas experimentais observou-se que o milho e a silagem de milho apresentaram maiores teores de carboidratos totais (CT), com valores de 128,3 e 464,8 g kg-1 matéria seca (MS) na fração B2, respectivamente. O menor teor de CT encontrado foi para o farelo de soja e a torta de crambe (TCr). Houve predomínio das frações A+B1 nos ingredientes e nas dietas experimentais. A fração B2 diminuiu nas dietas com a inclusão da proteína da TCr, e a TCr apresentou a maior fração C. No fracionamento de proteínas ( $\mathrm{g} \mathrm{kg}^{-1} \mathrm{MS}$ e $\mathrm{g} \mathrm{kg}^{-1}$ proteína bruta - $\mathrm{PB}$ ), os ingredientes e as dietas apresentaram maior proporção das frações A e B1+B2. Na degradação in vitro, a dieta sem $\operatorname{TCr}\left(0 \mathrm{~g} \mathrm{~kg}^{-1} \mathrm{MS}\right)$ apresentou a maior produção final cumulativa de gases $\left(365,04 \mathrm{~mL} \mathrm{~g}^{-1}\right.$ de MS incubada), enquanto que a TCr apresentou o menor volume (168,68 mL g-1 de MS incubada). O volume de gás da fermentação de carboidratos não fibrosos e taxa de degradação de carboidratos fibrosos exibiram um efeito quadrático de acordo com os níveis crescentes de TCr (Pmáx= $265.8 \mathrm{~g} \mathrm{~kg}^{-1} \mathrm{DM}$ e Pmin= $376.3 \mathrm{~g} \mathrm{~kg}^{-1} \mathrm{DM}$, respectivamente). $O$ tempo de latência e o volume final do gás apresentaram efeito linear decrescente com o aumento dos níveis de proteína da TCr. A taxa de degradação dos carboidratos não fibrosos e volume final de carboidratos não diferiram. A substituição da proteína do farelo de soja pela proteína da torta de crambe no nível de 
$250 \mathrm{~g} \mathrm{~kg}^{-1} \mathrm{MS}$ em dietas formuladas para cordeiros em confinamento leva a um bom perfil cinético de fermentação ruminal em relação à degradação de carboidratos fibrosos e não fibrosos.

Palavras-chave: Biodiesel. Coprodutos. Degradação in vitro. Fracionamento de carboidratos. Fracionamento de proteína.

\section{Introduction}

In recent years, the world has undergone major technological, environmental, social, and political changes. One of the current main challenges is the production of sustainable, nutritious, safe and accessible food for the world's population (Shurson, 2017).

Animal production systems have experienced great changes in the world technologies have been applied with the objective of increasing animal protein production. Animal feed is one of the most expensive factors in animal production, and several alternatives have emerged, including the use of agro-industrial residues as sustainable feed that minimizes environmental impact (Ajila et al., 2012). Countries such as Brazil and the United States have increased biofuel production from grains and oilseeds with the objective of reducing domestic dependence on oil, fostering competition between biofuels, the food industry and animal feed (Cooper \& Weber, 2013; Shurson, 2017).

Biofuel by-products are generated in the production of biofuels, demonstrate potential for use in animal feed and are generally used as ingredients in animal diets because they are economical and rich in nutrients (Ajila et al., 2012; Yang et al., 2021).

Crambe (Crambe abyssinica Hochst) is a plant originally from the Mediterranean with, the potential to generate biodiesel. Its seeds contain 460 to $580 \mathrm{~g} \mathrm{~kg}^{-1}$ of crude protein (CP) and 260 to $440 \mathrm{~g} \mathrm{~kg}^{-1}$ of ether extract (EE), and its oil is used as a lubricant in industry (Goes, Carneiro, Brabes \& Lana, 2016; Goes et al., 2010; R. H. X. Silva, 2014). The crambe cake (CC) is obtained after extracting the oil from the seed by pressing and it has a dry matter (DM) content between 870 and $940 \mathrm{~g} \mathrm{~kg}^{-1}, \mathrm{CP}$ contents from 240 to $340 \mathrm{~g} \mathrm{~kg}^{-1}$, EE contents from 180 to $290 \mathrm{~g} \mathrm{~kg}^{-1}$, neutral detergent fiber (NDF) content from 300 to $550 \mathrm{~g} \mathrm{~kg}^{-1}$, and acid detergent fiber (ADF) contents from 190 to $244 \mathrm{~g} \mathrm{~kg}^{-1}$ (A. L. Silva, 2013; Brás, Possenti, Bueno, Canova, \& Schammas, 2014; Canova, Bueno, Moreira, Possenti, \& Brás, 2015; Silva, Marcondes, Veloso, Souza, \& Knupp, 2015; Goes et al., 2016; Pegoraro et al., 2017; Goes et al., 2018). These characteristics make it possible to use it as a protein source in the feeding of lambs.

New technologies that allow nutritional assessment of new ingredients are required to accompany rapid hanges in animal production. In order to characterize the rumen metabolism of by-products and evaluate these ingredients, in vitro techniques are used to control experimental conditions and can be correlated with results obtained in vivo (Getachew, Blümmel, \& Makkar, 1998; Mizubuti et al., 2011). Gas production is proportional to the microbial fermentation of food and can be measured at frequent intervals, allowing the measurement of gas production by microbial action during the degradation process (Amanzougarene \& Fondevila, 2020). 
Methods for measuring ruminal fermentation kinetics are advantageous because they are rapid, accurate, and costeffective. In addition, these methods are simple and can be used to process many samples in a short time (Azarfar, Namgay \& Pellikaan, Tamminga, \& Van der Poel, 2009). A previous study by Mizubuti et al. (2011) evaluated various by-products and found that CC shows good performance in ruminal fermentation kinetics and has the potential to serve as an energy source in the diet of ruminants. A. L. Silva et al. (2015) studied the ruminal fermentation kinetics of 18 by-products of the biodiesel industry using the in vitro gas production technique, and concluded that forage radish cake, cottonseed, crambe and sunflower meal have the potential to replace soybean meal.

Thus, the objective of this study was to evaluate the in vitro ruminal fermentation kinetics of ingredients and diets containing increasing levels of crambe cake protein, replacing soybean meal protein in the diet of lambs.

\section{Material and Methods}

The experiment was carried out at the Animal Nutrition Laboratory of the Animal Science Department, State University of Londrina, and it was approved by the Ethics Committee CEUA_UEL under number 7748.2014 .28

The evaluated ingredients were: $\mathrm{CC}$, soybean meal, corn grain and corn silage. The evaluated diets (D) were formulated with the same ingredients and contained increasing levels of $\operatorname{CC}\left(0,250,500,750\right.$, and $\left.1000 \mathrm{~g} \mathrm{~kg}^{-1}\right)$ as a replacement for soybean meal protein in the concentrate ration. All diets were formulated to be isonitrogenous, and met the nutrient requirements of growing and finishing lambs (National Research Council [NRC], 2007), but a variation of up to $0.5 \%$ protein was allowed among them. The roughage: concentrate ratio was 30:70, using corn silage as roughage (Table 1). To formulate the diets, we used chemical compositions of ingredients determined at the Laboratory of Animal Nutrition, according to the methodologies described by Association of Official Analytical of Chemists [AOAC] (2016). 
Table 1

Chemical composition of ingredients and experimental diets

\begin{tabular}{|c|c|c|c|c|c|c|c|c|c|}
\hline Ingredients & $\begin{array}{c}\mathrm{DM}(\mathrm{g} \\
\left.\mathrm{kg}^{-1} \mathrm{NM}\right)\end{array}$ & $\mathrm{OM}$ & $\mathrm{CP}$ & \multicolumn{4}{|c|}{ ( $\left.\mathrm{g} \mathrm{kg}^{-1} \mathrm{DM}\right)$} & NFC & $\begin{array}{c}\mathrm{ME} \text { (Mcal } \\
\left.\mathrm{kg}^{-1} \mathrm{DM}\right)\end{array}$ \\
\hline Corn silage & 417.0 & 940.4 & 73.1 & 18.6 & 521.2 & 277.6 & 27.8 & 331.0 & 2.484 \\
\hline Corn grain & 848.0 & 986.2 & 91.6 & 35.0 & 142.2 & 27.2 & 10.6 & 701.0 & 3.153 \\
\hline Soybean meal & 871.9 & 936.1 & 455.2 & 11.9 & 130.9 & 52.1 & 0.6 & 217.4 & 3.092 \\
\hline Crambe cake & 915.6 & 940.4 & 280.5 & 275.5 & 328.2 & 232.4 & 1185 & 42.9 & 2.627 \\
\hline Urea & 976.8 & - & 2826.0 & - & - & - & - & - & - \\
\hline Mineral salt & 990.0 & - & 30.0 & - & - & - & - & - & 0.362 \\
\hline Limestone & 999.0 & - & - & - & - & - & - & - & - \\
\hline \multirow{2}{*}{ Ingredients } & \multicolumn{9}{|c|}{ Levels of crambe cake protein in the diets replacing soybean meal $\left(\mathrm{g} \mathrm{kg}^{-1} \mathrm{DM}\right)$} \\
\hline & 0 & & 250 & & 500 & & 750 & & 1000 \\
\hline Corn silage & 300.0 & & 300.0 & & 300.0 & & 300.0 & & 300.0 \\
\hline Corn grain & 384.8 & & 379.4 & & 373.9 & & 373.5 & & 363.1 \\
\hline Soybean meal & 295.0 & & 221.2 & & 147.5 & & 68.8 & & 0.00 \\
\hline Crambe cake & 0.0 & & 73.8 & & 147.5 & & 221.2 & & 295.0 \\
\hline Urea & 0.0 & & 5.0 & & 10.0 & & 15.0 & & 20.0 \\
\hline Mineral saltA & 10.0 & & 10.0 & & 10.0 & & 10.0 & & 10.0 \\
\hline Limestone & 10.2 & & 10.6 & & 11.1 & & 11.5 & & 11.9 \\
\hline \multicolumn{10}{|c|}{ Nutritional composition } \\
\hline $\mathrm{DM}\left(\mathrm{g} \mathrm{kg}^{-1} \mathrm{NM}\right)$ & 721.3 & & 725.3 & & 729.3 & & 733.2 & & 737.3 \\
\hline $\mathrm{OM}\left(\mathrm{g} \mathrm{kg}^{-1} \mathrm{DM}\right)$ & 954.3 & & 959.9 & & 959.6 & & 956.3 & & 948.2 \\
\hline $\mathrm{CP}\left(\mathrm{g} \mathrm{kg}^{-1} \mathrm{DM}\right)$ & 184.5 & & 183.6 & & 182.7 & & 179.9 & & 180.9 \\
\hline $\mathrm{EE}\left(\mathrm{g} \mathrm{kg}^{-1} \mathrm{DM}\right)$ & 19.7 & & 37.4 & & 55.0 & & 72.7 & & 90.3 \\
\hline NDF $\left(\mathrm{g} \mathrm{kg}^{-1} \mathrm{DM}\right)$ & 226.2 & & 239.3 & & 252.4 & & 265.5 & & 278.6 \\
\hline NDFap (g kg-1 DM) & 187.2 & & 216.1 & & 245.5 & & 271.3 & & 299.2 \\
\hline 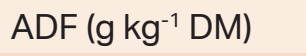 & 99.9 & & 112.0 & & 124.0 & & 126.0 & & 148.1 \\
\hline NDIN (g kg-1 DM) & 7.5 & & 8.6 & & 7.1 & & 10.3 & & 10.7 \\
\hline ADIN (g kg-1 DM) & 4.3 & & 3.6 & & 5.5 & & 5.2 & & 0.64 \\
\hline LIG (g kg-1 DM) & 12.5 & & 25.6 & & 52.0 & & 63.2 & & 63.3 \\
\hline ME (Mcal kg-1 DM) & 2.777 & & 2.795 & & 2.811 & & 2.829 & & 2.845 \\
\hline
\end{tabular}

$\mathrm{NM}=$ natural matter; $\mathrm{DM}=$ dry matter; $\mathrm{CP}=$ crude protein; $\mathrm{EE}=$ ether extract; $\mathrm{NDF}=$ neutral detergent fiber; $\mathrm{NDFap}=$ neutral detergent fiber corrected for ash and protein; $\mathrm{ADF}=$ acid detergent fiber; $\mathrm{NDIN}=$ neutral detergent insoluble nitrogen; $A D I N$ = acid detergent insoluble nitrogen; $L I G$ = lignin; $M E$ = metabolizable energy. The ME was calculated by formula of National Research Council (NRC, 2000): ME = TDN × 3.62; where TDN = total digestible nutrients.

${ }^{A}$ Composition: Calcium 135 g, Phosphor 65 g, Sodium 107 g, Sulfur 12 g, Magnesium 6,000 mg, Cobalt 175 mg, Cooper 100 mg, lodine 175 mg, Manganese 1,440 mg, Selenium 27 mg, Zinc 6,000 mg, Iron 1,000 mg, Fluorine 650 mg, Crude protein $30 \mathrm{~g}$ e TDN $100 \mathrm{~g}$. 
The method described by Sniffen, O'Connor, Van Soest, Fox and Russell (1992) was used to obtain the carbohydrate fractions, where:

Total carbohydrates: $\mathrm{TC}\left(\mathrm{g} \mathrm{kg}^{-1} \mathrm{DM}\right)=100-\mathrm{CP}$ ( $\left.\mathrm{g} \mathrm{kg}^{-1} \mathrm{DM}\right)$ - EE g kg-1 DM) - Ash $\left.\mathrm{g} \mathrm{kg}^{-1} \mathrm{DM}\right)$;

Fraction "A+B1" = $100-(B 2+C)$;

Fraction "B2" $\left(\mathrm{g} \mathrm{kg}^{-1} \mathrm{DM}\right)=$ NDFap - Fraction "C";

Fraction " $\mathrm{C}$ " $\left.\left(\mathrm{g} \mathrm{kg}^{-1} \mathrm{DM}\right)=\mathrm{NDF} \mathrm{g} \mathrm{kg}^{-1} \mathrm{DM}\right) \times$ $0.01 \times$ LIG $(\% N D F) \times 2.4$;

Fraction of non-fibrous carbohydrates (NFC) $=\mathrm{TC}\left(\mathrm{g} \mathrm{kg}^{-1} \mathrm{DM}\right)-$ fraction "B2" ( $\left.\mathrm{g} \mathrm{kg}^{-1} \mathrm{DM}\right)$ fraction "C" (g kg-1 DM);

where $\mathrm{DM}=$ dry matter; $\mathrm{CP}=$ crude protein $(\mathrm{N} \times 6.25) ; \mathrm{EE}=$ ether extract; $\mathrm{NDF}=$ neutral detergent fiber; NDFap $=$ neutral detergent fiber corrected for ash and protein; and LIG = lignin.

Nitrogenous compounds were fractionatedas described byLicitra, Hernandez, \& Van Soest (1996). Fraction A or nonprotein nitrogen (NPN) was calculated as the difference between the total $\mathrm{N}$ and $\mathrm{N}$-insoluble contents in trichloroacetic acid (TCA). Fraction "B3" was evaluated as the difference between neutral detergent insoluble nitrogen (NDIN) and acid detergent insoluble nitrogen (ADIN). Fraction " $\mathrm{C}$ " was obtained by determining ADIN. Fraction "B1 + B2" was obtained as the difference between the N insoluble in TCA and NDIN, or by subtracting from 100 the sum of fractions $\mathrm{A}, \mathrm{B} 3$, and $\mathrm{C}$.

The digestion rates of carbohydrate fractions (NFC and B2) were estimated using the gas production technique described by Pell and Schofield (1993) with some modifications. Approximately $300 \mathrm{mg}$ of each sample was incubated in glass vials $(50 \mathrm{~mL})$ in five replicates per sample. Five glass vials without substrate, considered white, were also incubated to discount the volume of gases from the ruminal liquid and buffer solution. 8mL McDougal buffer solution (McDougal, 1948), previously reduced by spraying with $\mathrm{CO}_{2}$, was added to each flask to adjust the $\mathrm{pH}$ (8.6) to the range of $6.8-7.0$, as well as more than $2 \mathrm{~mL}$ of ruminal liquid from rumen-fisted bovine. The buffer solution and inoculum were added under $\mathrm{CO}_{2}$ sparing to ensure anaerobic conditions. The vials were immediately covered with rubber caps and placed in a water bath at $39^{\circ} \mathrm{C}$. Depressurization was performed with needles prior to starting the incubation time to ensure that the pressure in the vials was under the same initial condition.

The pressure of gases produced by fermentation and that accumulated in the bottles was measured using an Instrutherm ${ }^{\circledR}$ MP-79 micro-manometer (São Paulo, Brazil) at 1, 2, 3, 4, 5, 6, 9, 12, 18, 24, 30, 36, $48,60,72,96$, and $144 \mathrm{~h}$ according to the recommendations of Mauricio et al. (1999). After each measurement, depressurization was performed (Pell \& Schofield, 1993).

The pressure $(P)$ values expressed in Psi were converted into volume $(\mathrm{V}, \mathrm{mL})$ according to a pre-established equation for local conditions: $V=0.5702+3.2399 \mathrm{P}+$ 0.1074P2 (R2 =0.99), corrected for $1 \mathrm{~g} \mathrm{DM}$ and subtracting the values obtained in the control vials.

To estimate the kinetic parameters of gas production, the data were adjusted using the bicompartmental logistic model (Schofield, Pitt, \& Pell, 1994) as follows: 


$$
V=\frac{V n f c}{\left[1+e^{(2-4 \times K n f c x(T-L))}\right]}+\frac{V c f}{\left[1+e^{(2-4 \times K f c x(T-L))}\right]}
$$

where $\mathrm{Vnfc}$ is the = maximum volume of gas production from non-fibrous carbohydrate fraction $\left(\mathrm{mL} \mathrm{g} \mathrm{g}^{-1}\right) ; \mathrm{Kdnfc}=$ degradation rate of non-fibrous carbohydrates $\left(\% \mathrm{~h}^{-1}\right) ; \mathrm{L}=$ colonization time (h); $\mathrm{Vfc}=$ maximum volume of gas production from the fibrous carbohydrate fraction $\left(\mathrm{mL} \mathrm{g}^{-1}\right) ; \mathrm{Kfc}=$ digestion rate for the fibrous carbohydrate fraction $\left(\% \mathrm{~h}^{-1}\right)$, and Vfinal $=$ the final volume of produced gas $(\mathrm{mL})$.

Subsequently, values for the parameters of ruminal degradation kinetics were generated from the R Core Team(2016) with the Gauss-Newton algorithm and then subjected to analysis of variance and regression (when necessary) according to a completely randomized experimental design with five treatments and five replications. A significance level of 0.05 was set.

\section{Results and Discussion}

In the carbohydrate fractionation of ingredients and experimental diets (Table 2 ), it was observed that corn grain and corn silage presented the highest levels of $\mathrm{TC}$, with values of 128.3 and $464.8 \mathrm{~g} \mathrm{~kg}^{-1} \mathrm{DM}$ in fraction B2, respectively. A lower TC content was found in soybean meal and $\mathrm{CC}$, and this result may be related to the $\mathrm{CP}$ and $\mathrm{EE}$ contents of these ingredients, which was reflected in the diets, mainly in the one that contains $100 \%$ substitution of soybean meal by CC. Similar results were observed by Carvalho (2012) when characterizing different ingredients in ruminants.

\section{Table 2}

Carbohydrates fractionation of ingredients and experimental diets with crambe cake protein $\left(\mathrm{g} \mathrm{kg}^{-1}\right.$ DM) replacing soybean meal protein

\begin{tabular}{lccccc} 
& \multicolumn{5}{c}{ Fractionation of carbohydrates } \\
\cline { 2 - 5 } Ingredients & $\begin{array}{c}\mathrm{TC} \\
\left(\mathrm{g} \mathrm{kg}^{-1} \mathrm{DM}\right)\end{array}$ & $\begin{array}{c}\mathrm{NFC} \\
\left(\mathrm{g} \mathrm{kg}^{-1} \mathrm{DM}\right)\end{array}$ & $\begin{array}{c}\mathrm{A}+\mathrm{B} 1 \\
\left(\mathrm{~g} \mathrm{~kg}^{-1} \mathrm{TC}\right)\end{array}$ & $\begin{array}{c}\mathrm{B} 2 \\
\left(\mathrm{~g} \mathrm{~kg}^{-1} \mathrm{TC}\right)\end{array}$ & $\begin{array}{c}\mathrm{C} \\
\left(\mathrm{g} \mathrm{kg}^{-1} \mathrm{TC}\right)\end{array}$ \\
\hline Crambe cake & 384.5 & 42.9 & 658.4 & 57.1 & 284.4 \\
Corn grain & 859.7 & 706.0 & 846.4 & 128.3 & 25.4 \\
Soybean meal & 357.4 & 217.3 & 860.0 & 138.7 & 1.4 \\
Corn silage & 862.6 & 331.0 & 468.5 & 464.8 & 66.7 \\
Experimental diets & & & & \\
0 & 715.2 & 455.3 & 740.1 & 229.7 & 30.2 \\
250 & 717.9 & 444.0 & 726.1 & 223.0 & 50.9 \\
500 & 748.6 & 450.9 & 702.4 & 230.2 & 67.4 \\
750 & 726.0 & 424.0 & 698.0 & 209.5 & 92.5 \\
1000 & 726.2 & 410.2 & 684.0 & 202.9 & 113.1
\end{tabular}

ITC = Total carbohydrates; CNF= Non fibrous carbohydrates. 
A predominance of fractions $A+B 1$ (soluble sugars, starch, pectin) was observed in ingredients and experimental diets (Table 2 ), indicating that they are good sources of energy for the growth of microorganisms that degrade NFC and have an important effect on the end products of fermentation (Santo et al., 2017). According to Santos et al. (2020), it is necessary to include protein sources of rapid and medium degradation in the rumen when the $\mathrm{A}+\mathrm{B} 1$ fraction constitutes the main fraction of carbohydrates in the diet. Similar results were observed by Viana et al. (2012) and Mizubuti et al. (2014) who fractioned carbohydrates and proteins from different foods.

Among the ingredients, corn silage showed a high value of fraction B2, however, in the replacement of soybean meal protein by $\mathrm{CC}$, this fraction decreased in the diets (Table 2). Fraction B2 is the main component of tropical forages, as it presents a slow rate of degradation and supplies energy more slowly in the rumen influencing the efficiency of microbial synthesis (Viana et al., 2012; Pegoraro et al., 2017). Therefore, NPN sources are required to meet the $\mathrm{N}$ demand of fermenting microorganisms for structural carbohydrates (Russell, O'Connor,Van Soest, \& Sniffen, 1992).

CC presented the highest $\mathrm{C}$ fraction, probably due to the high lignin content $(118,50$ $\mathrm{g} \mathrm{kg}^{-1} \mathrm{DM}$ ) in this by-product (Table 1). This fraction increased with the CC levels in the diet (Table 2). Fraction $\mathrm{C}$ is the portion unavailable to rumen microorganisms or to the animal, and high values may cause less digestibility of carbohydrates contained in the diet. R. B. Silva (2013) and Canova et al. (2015) observed a linear decrease in the apparent digestibility coefficient of NDF and ADF as a function of increased $\mathrm{CC}$ levels in the diets.
In the protein fractionation $\left(\mathrm{g} \mathrm{kg}^{-1}\right.$ $\mathrm{DM}$ and $\mathrm{g} \mathrm{kg}^{-1} \mathrm{CP}$ ), the ingredients and diets showed a higher proportion of fractions $A$ and B1 + B2 (Table 3), indicating that they contain proteins with rapid availability and degradability in the rumen.

According to Sniffen et al. (1992), it is necessary to fractionate the feed used by ruminants to adequately evaluate and balance the diets. With protein fractionation, it is possible to more precisely control food rations, as well as predict the digestibility of proteins through models or prediction equations (Carrera et al., 2012).

According to Pegoraro et al. (2017), fraction $A$ can be converted quickly into ammonia and may be superior or event necessary for the growth of microorganisms. In this way, excess ammonia is absorbed through the rumen wall, metabolized in the liver or passed to the posterior digestive compartments. Carvalho (2012) affirmed that it is necessary to synchronize the fermentation of proteins and carbohydrates to avoid the loss of ammonia and include ingredients in diets that contain carbohydrates for rapid ruminal degradation. In this study, diets were balanced in relation to the rapidly degradable fractions in the rumen of both carbohydrates and proteins.

Similar results were found by Carrera et al. (2012), who evaluated different co-products and observed that $\mathrm{CC}$ and soybean had high values for fractions $A(433.1$ and $540.0 \mathrm{~g}$ $\mathrm{kg}^{-1} \mathrm{CP}$ ), B1 (36.0 and $1.5 \mathrm{~g} \mathrm{~kg}^{-1} \mathrm{CP}$ ), and B2 (467.2 and $793.9 \mathrm{~g} \mathrm{~kg}^{-1} \mathrm{CP}$ ), respectively. This confirms that these ingredients have a good protein profile and low fractions of B3 and $\mathrm{C}$, indicating good ruminal degradability. 


\section{Table 3}

Protein fractionation of ingredients and experimental diets with crambe cake protein (g kg-1 DM) replacing soybean meal protein

\begin{tabular}{|c|c|c|c|c|c|}
\hline \multirow{2}{*}{ Ingredients } & \multicolumn{5}{|c|}{ Protein fractionation ( $\left.\mathrm{g} \mathrm{kg}^{-1} \mathrm{DM}\right)$} \\
\hline & $\mathrm{CPI}$ & A & $\mathrm{B} 1+\mathrm{B} 2$ & B3 & C \\
\hline Crambe cake & 280.5 & 111.5 & 155.6 & 4.2 & 9.2 \\
\hline Corn grain & 91.6 & 12.3 & 68.1 & 8.6 & 2.6 \\
\hline Soybean meal & 566.9 & 142.7 & 415.1 & 6.9 & 2.2 \\
\hline Corn silage & 73.1 & 31.0 & 31.6 & 4.1 & 6.3 \\
\hline \multicolumn{6}{|c|}{ Experimental diets } \\
\hline 0 & 224.4 & 56.1 & 158.1 & 6.6 & 3.6 \\
\hline 250 & 202.7 & 53.7 & 138.6 & 6.3 & 4.1 \\
\hline 500 & 189.8 & 48.0 & 131.3 & 5.8 & 4.6 \\
\hline 750 & 157.2 & 48.4 & 97.9 & 5.8 & 5.1 \\
\hline \multirow[t]{2}{*}{1000} & 137.9 & 46.6 & 80.1 & 5.6 & 5.6 \\
\hline & \multicolumn{5}{|c|}{ Protein fractionation $\left(\mathrm{g} \mathrm{kg}^{-1} \mathrm{CP}\right)$} \\
\hline Crambe cake & 280.5 & 397.4 & 554.7 & 15.2 & 32.7 \\
\hline Corn grain & 91.6 & 133.8 & 744.0 & 94.0 & 28.1 \\
\hline Soybean meal & 566.9 & 251.7 & 732.2 & 12.2 & 3.9 \\
\hline Corn silage & 73.1 & 424.8 & 432.8 & 55.7 & 86.7 \\
\hline \multicolumn{6}{|c|}{ Experimental diets } \\
\hline 0 & 224.4 & 250.1 & 704.8 & 29.3 & 15.8 \\
\hline 250 & 202.7 & 265.1 & 683.7 & 31.2 & 20.0 \\
\hline 500 & 189.8 & 253.2 & 692.1 & 30.8 & 24.0 \\
\hline 750 & 157.2 & 307.7 & 622.9 & 37.2 & 32.1 \\
\hline 1000 & 137.9 & 338.2 & 580.9 & 40.6 & 40.2 \\
\hline
\end{tabular}

'CP = Crude protein.

There was variation in the kinetic parameters of in vitro carbohydrate degradation in the experimental diets (Table 4). Vnfc showed a quadratic effect as a function of the $\mathrm{CC}$ levels, with a maximum point of $265.8 \mathrm{~g} \mathrm{~kg}^{-1}$. Kdfc also presented a quadratic effect as a function of the $\mathrm{CC}$ levels with minimum point of $376.3 \mathrm{~g} \mathrm{~kg}^{-1}$. $\mathrm{L}$ and Vfinal showed a decreasing linear effect on CC levels (Table 4). 


\section{Table 4}

\section{Kinetic parameters of in vitro carbohydrate degradation of experimental diets with crambe cake protein} replacing soybean meal protein

\begin{tabular}{|c|c|c|c|c|c|c|c|c|}
\hline \multirow{2}{*}{ Parameters' } & \multicolumn{5}{|c|}{ Levels of crambe cake ( $\left.\mathrm{g} \mathrm{kg}^{-1} \mathrm{DM}\right)$} & \multicolumn{2}{|c|}{ P-value } & \multirow{2}{*}{$\begin{array}{l}\text { CV } \\
\text { (\%) }\end{array}$} \\
\hline & 0 & 250 & 500 & 750 & 1000 & L & $Q$ & \\
\hline Vncf (mL) & 17.97 & 24.78 & 17.78 & 15.32 & 11.80 & 0.001 & 0.003 & 31.50 \\
\hline Kdncf $\left(\% h^{-1}\right)$ & 0.08 & 0.06 & 0.09 & 0.08 & 0.08 & 0.508 & 0.474 & 29.05 \\
\hline$L(h)$ & 4.17 & 4.19 & 3.79 & 3.47 & 3.19 & 0.001 & 0.305 & 12.87 \\
\hline $\mathrm{Vfc}(\mathrm{mL})$ & 18.54 & 8.49 & 12.84 & 13.44 & 11.56 & 0.211 & 0.139 & 40.65 \\
\hline $\operatorname{Kdfc}\left(\% \mathrm{~h}^{-1}\right)$ & 0.02 & 0.02 & 0.02 & 0.03 & 0.03 & 0.078 & 0.041 & 21.93 \\
\hline Vfinal $(\mathrm{mL})$ & 365.0 & 332.6 & 306.19 & 287.65 & 233.61 & 0.001 & 0.540 & 15.67 \\
\hline \multirow[b]{2}{*}{ Ingredients } & \multicolumn{8}{|c|}{ Parameters ${ }^{\prime}$} \\
\hline & \multicolumn{2}{|l|}{$\begin{array}{l}\text { Venf } \\
\text { (mL) }\end{array}$} & $\begin{array}{l}\text { Kdcnf } \\
(\% / h)\end{array}$ & $\begin{array}{l}\mathrm{L} \\
\text { (h) }\end{array}$ & $\begin{array}{l}\text { Vcf } \\
(\mathrm{mL})\end{array}$ & \multicolumn{2}{|c|}{$\begin{array}{c}\text { Kdcf } \\
\left(\% h^{-1}\right)\end{array}$} & $\begin{array}{c}\text { Vfinal } \\
(\mathrm{mL})\end{array}$ \\
\hline Crambe cake & \multicolumn{2}{|l|}{49.29} & 0.18 & 2.34 & 117.10 & \multicolumn{2}{|c|}{0.03} & 166.54 \\
\hline CV (\%) & \multicolumn{2}{|l|}{11.80} & 11.39 & 22.21 & 8.05 & \multicolumn{2}{|c|}{3.40} & 2.77 \\
\hline Corn grain & \multicolumn{2}{|l|}{47.72} & 0.40 & 4.85 & 344.34 & \multicolumn{2}{|c|}{0.02} & 392.05 \\
\hline CV (\%) & \multicolumn{2}{|l|}{4.10} & 10.32 & 3.75 & 2.20 & \multicolumn{2}{|c|}{5.03} & 1.94 \\
\hline Soybean meal & \multicolumn{2}{|l|}{175.62} & 0.06 & 3.40 & 93.41 & \multicolumn{2}{|c|}{0.02} & 271.00 \\
\hline CV (\%) & \multicolumn{2}{|l|}{3.76} & 6.79 & 7.62 & 11.89 & \multicolumn{2}{|c|}{5.21} & 2.12 \\
\hline Corn silage & \multicolumn{2}{|l|}{43.70} & 0.20 & 5.11 & 264.30 & \multicolumn{2}{|c|}{0.02} & 328.17 \\
\hline CV (\%) & \multicolumn{2}{|l|}{26.36} & 33.52 & 20.38 & 8.57 & & & 6.54 \\
\hline
\end{tabular}

'Vncf: Volume of gas production of non-fibrous carbohydrate fraction, Kdncf: Rate of degradation of non-fibrous carbohydrate, Vcf: Gas volume of fibrous carbohydrate fermentation, Kdcf: Rate of fibrous carbohydrate degradation, Vfinal: final volume. $L=$ Linear effect: Lag time= 0.4174-0.002062x $\left(R^{2}=0.94\right) ;$ Vfinal $=63.50-0.09417 x(R=0.92)$. $Q=$ Quadratic effect: Vncf $=1.955+0.01010 x-0.00019 x^{2}\left(P \operatorname{máx}=265.8 ; R^{2}=0.73\right) ; \mathrm{Kdfc}=0.002628-0.00001613 x+0.0000002$ $143 x^{2}\left(P \min =376.3 ; R^{2}=0.59\right)$.

After $144 \mathrm{~h}$ of incubation, the ration without CC $(0 \mathrm{~g} \mathrm{~kg}-1)$ showed the highest final volume of cumulative gas production (365.04 $\mathrm{mL}$ g-1 DM incubated) (Figure 1). Thus, as shown in Figure 1, $750 \mathrm{~g} \mathrm{~kg}-1 \mathrm{DM}$ and $1000 \mathrm{~g}$ kg-1 DM of CC led to lower gas accumulation; however, in terms of the final volume of gas, all treatments produiced approximately $500 \mathrm{~g}$ $\mathrm{kg}-1$ gas in up to $48 \mathrm{~h}$.

Concerning incubation time, Mizubuti et al. (2011) stated that the retention time of food in the rumen is $48 \mathrm{~h}$, and the greatest degradation up to this time results in better fermentative quality of food (Figure 1).
According to Nogueira, Maurício, \& Gonçalves (2006), the volume of gas produced depends on the food composition. In general, a higher fiber content results in greater gas production, and a higher starch content results in lower gas production. However, in this study, diets with higher starch contents showed similar levels of gas production to those of high-fiber diets.

The ingredient with the lowest volume of gas produced after $144 \mathrm{~h}$ of incubation was CC, with a value of $166.54 \mathrm{~mL}$; for soybean meal, this value was $271.00 \mathrm{~mL}$. However, corn and corn silage displayed 
the highest gas accumulation (392.17 and $328.17 \mathrm{~mL}$, respectively) (Figure 2). The major volume of gas produced by corn grain and corn silage was due the decrease in $\mathrm{pH}$ after $12 \mathrm{~h}$ of incubation. Evaluating the use of cryopreserved ruminal liquid in the gas production technique Gülşen, Arik, Hayirli, Alatas and Aksoy (2017) observed that foods rich in starch produced higher amounts of gas production than protein foods die to, the decrease in $\mathrm{pH}$ after $12 \mathrm{~h}$ of incubation.

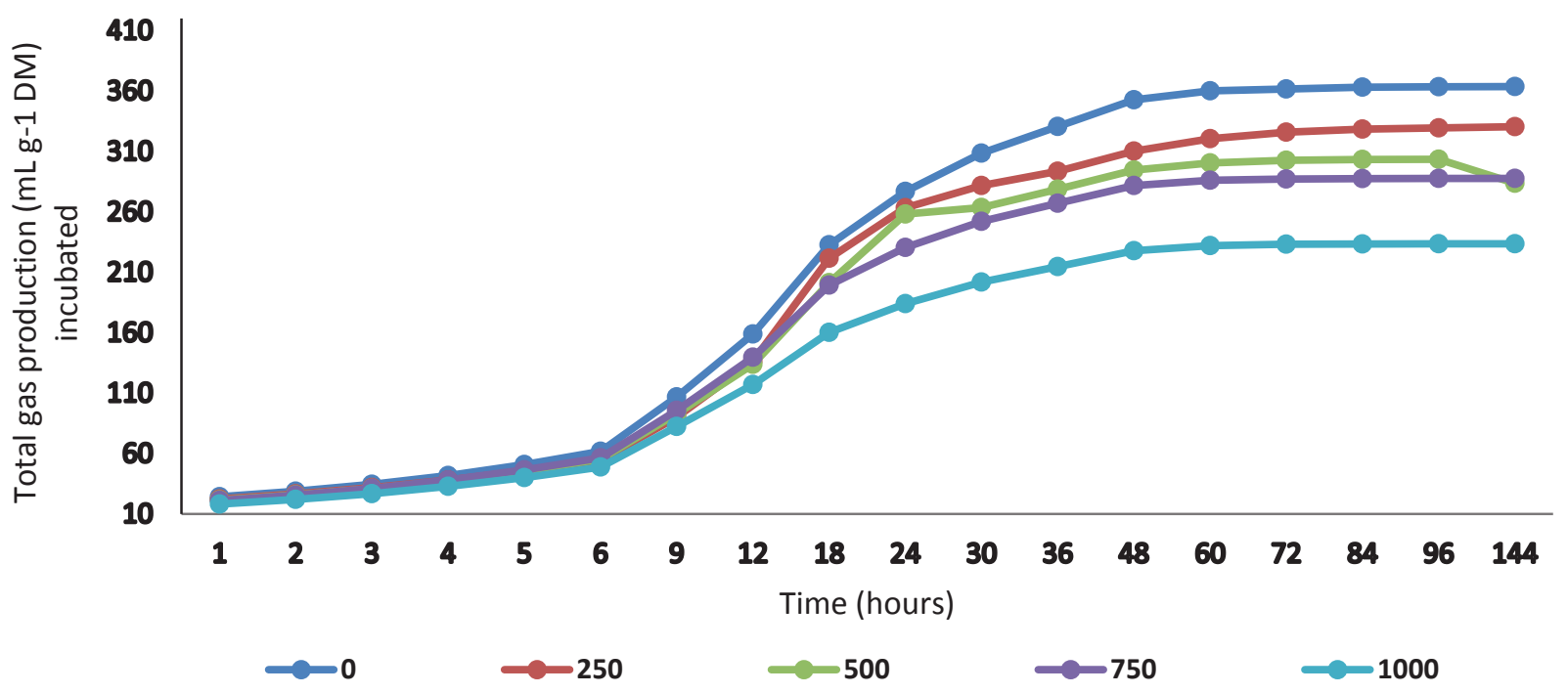

Figure 1. Total gas production ( $\mathrm{mL} \mathrm{g}^{-1}$ of dry matter - DM) of diets containing increasing levels of crambe cake $\left(\mathrm{g} \mathrm{kg}^{-1} \mathrm{DM}\right)$ replacing soybean meal protein as a function of incubation times.

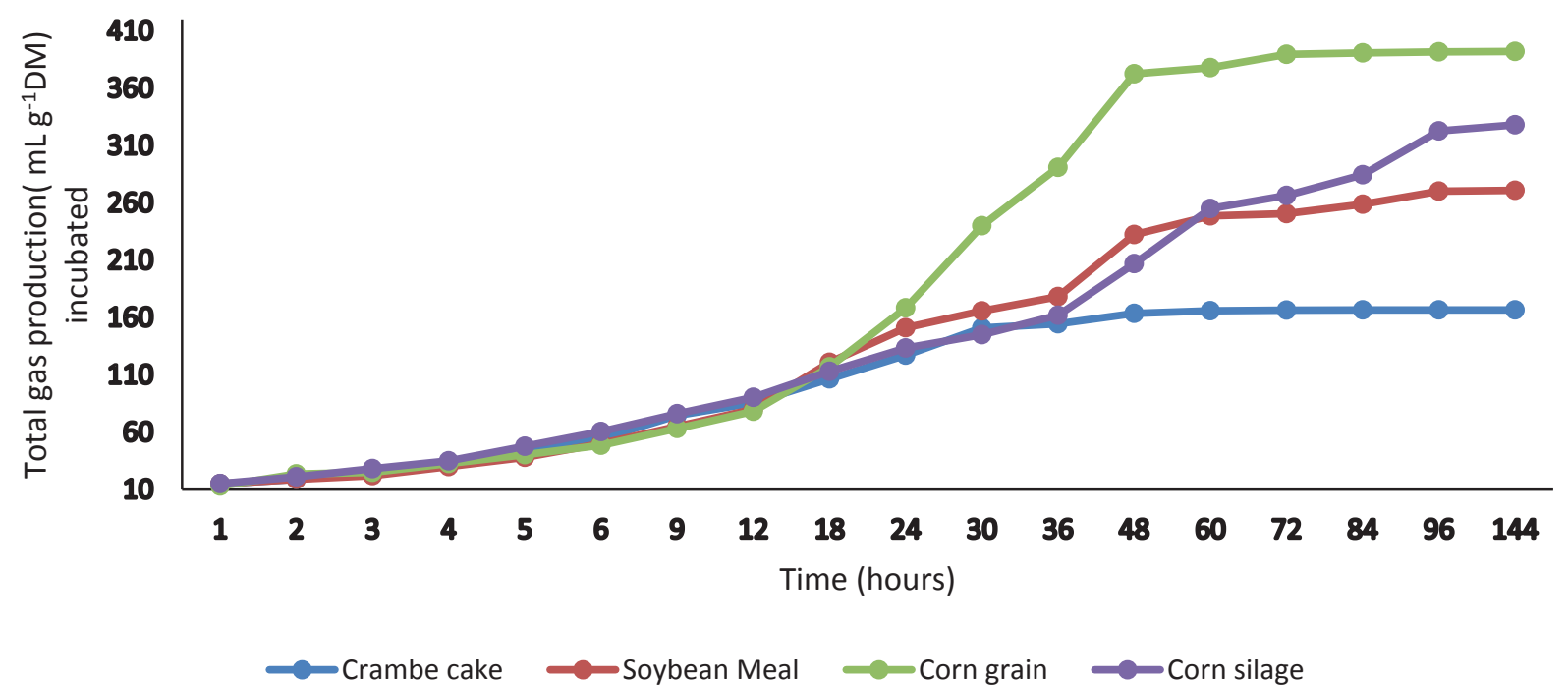

Figure 2. Total gas production ( $\mathrm{mL} \mathrm{g-11}$ of dry matter $-\mathrm{DM}$ ) from crambe cake, soybean meal, corn grain and corn silage as a function of incubation times. 
The low degradation rate of fibrous carbohydrates in the rations can cause a ruminal repletion effect, limiting the DM intake and impairing the performance of the animals (Mizubuti et al., 2011).

$\mathrm{L}$ indicates the time between the beginning of incubation and microbial action on the rations and the presence of readily fermentable soluble substances facilitates microbial colonization, reducing the time to colonization. The shortest $L$ can be attributed to the physicochemical characteristics of CC.

According to Cabral et al. (2020), the lag time can also be influenced by the inoculum, as once collected, after 12 hours of fasting, it can result in depletion of the microbiota, requiring a longer incubation time. R. H. X. Silva (2014) evaluated two diets with different levels of CC $\left(0,50,100\right.$ and $150 \mathrm{~g} \mathrm{~kg}^{-1}$; and 0, 25, 50, 100 and $150 \mathrm{~g} \mathrm{~kg}^{-1}$, respectively) and observed that $\mathrm{CC}$ did not influence $\mathrm{L}$.

Another contributing factor is the glucosinolate content (not determined in this study), of which, according to Tripathi \& Mishra (2007), crambe by-products contain 80 to $100 \mathrm{~g} \mathrm{~kg}^{-1}$, with $90 \%$ being naturally transformed into epigoitrine. According to Gao et al. (2021) glucosinolates are converted by rumen microorganisms into potentially less toxic compounds, favoring their use in the preparation of diets for this animal species. Furthermore, glucosinolates can improve the richness of the ruminal microbiota and, in this case, favor cellulolytic bacteria because as the CC levels increased, the NDF content of the diets also increased.

The values found for the final volume of fibrous carbohydrates indicate that the rations exhibit similar ruminal fermentation levels, indicating a balance between energy and nitrogenous compounds supplied (Mizubuti et al., 2011). This is probably reflected in the production of short-chain fatty acids (SCFAs), which are the main source of energy for ruminants (Calder, 2016).

Although SCFA was not quantified in this study, microorganisms probably colonized the most fibrous particles, mainly in diets that contained less $\mathrm{CC}$, increasing gas production when compared to diets with higher CC levels that is, with higher contents of lignin (Morais et al., 2015). According to Amanzougarene and Fondevila (2020), there is a significant correlation between SCFA and gas production. The amount of gas released from carbohydrates is influenced by the chemical nature that determines the metabolic pathway its relationship with other feed components such as lignin, protein and tannins, which can modulate the fermentation rate. The SCFA proportions depend on the type of substrate, with rapidly fermentable carbohydrates producing greater amounts of propionate than acetate, if there is a greater amount of slow fermenting carbohydrates, greater production of acetate than propionate occurs (Getachew et al., 1998).

The ruminal kinetic parameters for CC (Table 4) differed from those reported by Mizubuti et al. (2011) and A. L. Silva et al. (2015) for Vnfc, L, and Vfc. These differences were likely related to the temperature used in the production of $\mathrm{CC}$, NFC content, and EE content of this co-product. The variations observed between ingredients may be related to the conditions and composition of the soil where they were grown, climatic factors, and others variables. 


\section{Conclusion}

Replacing soybean meal protein with crambe cake protein at level of $250 \mathrm{~g} \mathrm{~kg}^{-1}$ of dry matter in diets formulated for feedlot lambs leads to good profiles of ruminal fermentation kinetics with respect to the degradation of fibrous and non-fibrous carbohydrates.

\section{Acknowledgements}

To Araucária Foundation and National Council for Scientific and Technological Development (CNPq), for funding this research project and for financing the post-doctoral research grant of Poveda- Parra, A.; to the Agricultural Engineer Carlos Pitol; to the MS Foundation for the Research and Diffusion of Agricultural Technologies and Coordination for the Improvement of Higher Education Personnel (CAPES).

\section{References}

Ajila, C. M., Brar, K. K., Verma, M., Tyagi, R. D., Godbout, S., \& Valéro, J. R. (2012). Bioprocessing of agro-byproducts to animal feed. Critical Reviews in Biotechnology, 32(4), 1-19. doi: 10.3109/07388551.20 12.659172

Amanzougarene, Z., \& Fondevila, M. (2020). Fitting of the in vitro gas production technique to the study of high concentrate diets. Animals, 10, 1935. doi: 10.3390/ ani10101935

Association of Official Analytical of Chemists (2016). Official methods of analytical of the association of official analytical of chemists (20nd ed.). Washington: AOAC.
Azarfar, A., Namgay, K., Pellikaan, W., Tamminga, S., \& Van der Poel, A. F. B. (2009). In vitro gas production profiles and fermentation end-products in processed barley, maize and milo. Journal Science Food Agriculture, 89(10), 1697-1708. doi: 10.1002/JSFA.3643

Brás, P., Possenti, R. A., Bueno, M. S., Canova, E. B., \& Schammas, E. A. (2014). Avaliação nutricional de coprodutos da extração de óleos vegetais em dietas de ovinos. Boletim de Industria Animal, 71(2), 160175. doi: 10.17523/bia.v71n2p160

Cabral, Í. S., Oliveira, S. S., Azevêdo, J. A. G., Souza, L. L., Lima, R. F., Lopes, C. C., Sousa, C. A. F. (2020). Ruminal fermentation kinetics of by-products using the semiautomatic technique of in-vitro gas production. Revista Brasileira de Saúde e Produção Animal, 21(1), 1-8. doi: 10.1590/ S1519-99402121242020

Calder, P. C. (2016). Fatty acids: metabolism. In B. Caballero, P. M. Finglas, \& F. Toldrá (Eds.), Encyclopedia of food and health (pp. 632644). Oxford: Academic Press.

Canova, E. B., Bueno, M. S., Moreira, H. L., Possenti, R., \& Brás, P. (2015). Crambe cake (Crambe abyssinica hoschst) on lambs diets. Ciência e Agrotecnologia, 39(1), 75-81. doi: 10.1590/S1413-70542 015000100009

Carrera, R. A. B., Veloso, C. M., Knupp, L. S., Souza, A. H., Jr., Detmann, E., \& Lana, R. P. (2012). Protein co-products and byproducts of the biodiesel industry for ruminants feeding. Revista Brasileira de Zootecnia, 41(5), 1202-121. doi: 10.1590/ S1516-35982012000500018 
Carvalho, E. M. (2012). Caracterização de alimentos para ruminantes segundo o Cornell net carbohydrate and protein system - CNCPS com adaptações. Tese de doutorado, Universidade Federal de Viçosa, Viçosa, MG, Brasil.

Cooper, G., \& Weber, A. (2013). An outlook on world biofuel production and its implications for the animal feed industry. In H. P. S. Makkar (Ed.), Biofuel co-products as livestock feed: opportunities and challenges (pp. 1-12). Rome: Food Agric. Organ.

Gao, J., Sun, Y., Bao, Y., Zhou, K., Kong, D., \& Zhao, G. (2021). Effects of different levels of rapessed cake containing high glucosinolates in steer ration on rumen fermentation, nutrient digestibility and the rumen microbial community. British Journal of Nutrition, 125(3), 1-25. doi: $101.1017 / S 0007114520002767$

Getachew, M. G., Blümmel, H. P.S., \&Makkar, K. B. (1998). In vitro gas measuring techniques for assessment of nutritional quality of feeds: a review. Animal Feed Science and Technology, 72,(2-4), 261-281. doi: 10.1016/S0377-8401(97)00189-2

Goes, R. H. T. B., Carneiro, M. M. Y., Brabes, K. C. S., \& Lana, R. P. (2016). Coprodutos de crambe (Crambe abyssinica Hoechst) na alimentação de ruminantes. Archivos de Zootecnia, 65(249), 7-16. doi: 10.21071/ az.v65i249.450

Goes, R. H. T. B., Carneiro, M. M. Y., Osmari, M. P., Souza, K. A., Oliveira, R. T., \& Souza, C. J. S. (2018). Intake, digestibility, performance and carcass characteristics of ewes fed crambe replacing soybean meal in the diet. Acta Scientiarum Animal Sciences, 40, e37171. doi: 10.4025/actascianimsci. v40i1.37171
Goes, R. H. T. B., Souza, K. A., Patussi, R. A., Cornelio, T. C., Oliveira, E. R., \& Brabes, K. C. S. (2010). Degradabilidade in situ dos grãos de crambe, girassol e soja e de seus coprodutos em ovinos. Acta Scientarum Animal Sciences, 32(3), 271-277. doi: 10. 4025/actascianimsci.v32i3.7913

Gülşen, N., Arik, H. D., Hayirli, A., Alatas, M. S., \& Aksoy, M. (2017). Utilization of cryopreserved ruminal liquor in in vitro gas production technique for evaluating nutritive value of some feedstuffs. Kafkas Universitesi Veteriner Fakültesi Dergisi, 23(2), 325-332. doi:10.9775/ kvfd.2016.16527

Licitra, G., Hernandez, T. M., \& Van Soest, P. J. (1996). Standardization of procedures for nitrogen fractionation of ruminant feeds. Animal Feed Science and Technology, 57(4), 347-358. doi: 10.1016/0377-8401 (95)00837-3

Mauricio, R. M., Mould, F. L., Dhanoa, M. S., Owen, E., Channa, K. S., \& Theodorou, M. K. (1999). A semi-automated in vitro gas production technique for ruminants feedstuff evaluation. Animal Feed Science and Technology, 79(4), 321-330. doi: 10. 1016/S0377-8401(99)00033-4

McDougal, E. I. (1948). Studies on ruminal saliva. The composition and output of sheep's saliva. Biochemical Journal, 43(1), 99-109. doi: 10.1042/bj0430099

Mizubuti, I. Y., Ribeiro, E. L. A., Pereira, E. S., Peixoto, E. L. T., Moura, E. S., Prado, O. P. P.,... Cruz, J. M. C. (2014). Cinética de degradação ruminal de alimentos proteicos pela técnica in vitro de produção de gases. Semina: Ciências Agrárias, 35(1), 555-566. doi: 10.5433/1679-0359.2014v35n1p555 
Mizubuti, I. Y., Ribeiro, E. L. A., Pereira, E. S., Pinto, A. P., Franco, A. L. C., Syperreck, M. A.,.. Muniz, E. B. (2011). Cinética de fermentação ruminal in vitro de alguns co-produtos gerados na cadeia produtiva do biodiesel pela técnica de produção de gás. Semina: Ciências Agrárias, 32(Supl. 1), 2021-2028. doi: 10. 5433/1679-0359.2011v32n4Sup1p2021

Morais, R. K. O., Silva, A. M. A., Bezerra, L. R., Carneiro, H., Moreira, M. N., \& Medeiros, F. F. (2015). In vitro degradation and total gas production of byproducts generated in the biodiesel production chain. Acta Scientiarum. Animal Sciences, 37(2), 143148. doi: 10.4025/actascianimsci.v37i2. 26309

National Research Council (2000). Nutrient requirements of beef cattle. Washington, USA: National Academies Press.

National Research Council (2007). Nutrient requirements of small ruminants: sheep, goats, cervids and new world camelids. Washington, USA: National Academies Press.

Nogueira, U. T., Maurício, R. M., \& Gonçalves, L. C. (2006). Comparação de substratos com diferentes quantidades de carboidratos solúveis utilizando a técnica in vitro semi-automática de produção de gases. Arquivo Brasileiro de Medicina Veterinária, 58(4), 901-909. doi: 10.1590/ S0102-09352006000400027

Pegoraro, M., Silva, L. D. F., Fernandes, F., Jr., Massaro, F. L., Jr, Fortaleza, A. P. S., Grandis, F. A.,... Castro, F. A. B. (2017). Avaliação nutricional e cinética de degradação in vitro de concentrados proteicos utilizados na alimentação de ruminantes. Revista Brasileira de Ciência
Veterinária, 24(1), 31-38. doi: 10.4322/ rbcv.2017.007

Pell, A. N., \& Schofield, P. (1993). Computerized monitoring of gas production to measure forage digestion in vitro. Journal of Dairy Science, 76(9), 1063-1073. doi: 10.3168/ jds.S0022-0302(93)77435-4

R Core Team (2016). R: A language and environment for statistical computing. $\mathrm{R}$ Foundation for statistical computing.

Russell, J. B., O'Connor, J. D. O., Van Soest, P. J., \& Sniffen, C. J. (1992). A net carbohydrate and protein system for evaluating cattle diets: I. Ruminal fermentation. Journal of Animal Science, 70(11), 3551-3561. doi: 10.2527/1992.70113551x

Santo, A. X., Silva, L. D. F., Lançanova, J. A. C., Ribeiro, E. L. A., Mizubuti, I. Y., Fortaleza, A. P. S., Henz, É. L., Júnior, F. L. M. (2017). Fracionamento de carboidratos e proteínas, cinética de degradação ruminal in vitro pela técnica de produção de gás, de rações suplementares contendo torta de girassol. Arquivo de Medicina Veterinária e Zootecnia, 69(5), 234-242. doi: 10.1590/1678-4162-8761

Santos, L. C., Nascimento, W. G., Azevedo, M. M. R., Silva, D. K. A., Macedo, I. M., \& Soares, G. S. C. (2020). Bromatological quality of silagefromcassavaresidues:fractionation of proteins and carbohydrates. Revista Brasileira de Saúde e Produção Animal, 21, 1-13. doi: 10.1590/S1519-99402121 302020

Schofield, P., Pitt, R. E., \& Pell, A. N. (1994). Kinetics of fiber digestion from in vitro gas production. Journal of Animal Science, 72(11), 2980-2991. doi: 10.25 27/1994.72112980x 
Shurson, G. C. (2017). The role of biofuels coproducts in feeding the world sustainably. Annual Review Animal Bioscience, 5, 5.1-5.26. doi: 10.1146/ annurev-animal-022516-022907

Silva, A. L., Marcondes, M. I., Veloso, C. M., Sousa, F. C., \& Knupp, L. S. (2015). Simulation of rumen fermentation kinetics of byproducts from the biodiesel industry with in vitro gas production technique. Semina: Ciências Agrárias, 36(6), 3851-3862. doi: 10.5433/1679-0359.2015v36n6p3851

Silva, R. B. (2013). Substituição do farelo de soja por torta de crambe para ovinos em crescimento. Dissertação de mestrado, Universidade Federal de Lavras, Lavras, MG, Brasil.

Silva, R. H. X. (2014). Cinética de fermentação ruminal de dietas com coprodutos da cadeia produtiva do biodiesel. Dissertação de mestrado, Universidade Federal da Grande Dourados, Dourados، MS, Brasil.
Sniffen, C. J., O'connor, D. J., Van Soest, P. J., Fox, D. G., \& Russell, J. B. (1992). A net carbohydrate and protein system for evaluating cattle diets: carbohydrate and protein availability. Journal of Animal Science, 70(11), 3562-3577. doi: 10.25 27/1992.70113562x

Tripathi, M. K., \& Mishra, A. S. (2007). Glucosinolates in animal nutrition: a review. Animal Feed Science and Technology, 132(1), 1-27. doi: 10.1016/j. anifeedsci.2006.03.003

Viana, P. T., Pires, A. J.V., Oliveira, L. B., Carvalho, G. G. P. C., Ribeiro, L. S. O., Chagas, D. M. T., Carvalho, A. O. (2012). Fracionamento de carboidratos e de proteína das silagens de diferentes forrageiras. Revista Brasileira de Zootecnia, 41(2), 292-297. doi: 10. 1590/S1516-35982012000200009

Yang, K., Qing, Y., Yu, Q., Tang, X., Chen, G., Fang, R., \& Liu, H. (2021). By-products feeds: current understanding and future perspectives. Agriculture, 11(3), 1-19. doi: 10.3390/agriculture11030207 